\title{
The April 6, 2009, Mw 6.3, L'Aquila sequence: weak-motion and strong-motion data recorded by the RAIS temporary stations
}

\author{
Ezio D'Alema ${ }^{1}$, Simone Marzorati ${ }^{1}$, Marco Massa ${ }^{1}$, Gianlorenzo Franceschina ${ }^{1}$, Paolo Augliera ${ }^{1,}$
}

${ }^{1}$ Istituto Nazionale di Geofisica e Vulcanologia, sezione di Milano-Pavia, Milano, Italy

\author{
Article history \\ Received February 11, 2010; accepted July 14, 2010. \\ Subject classification: \\ Surveys, measurements and monitoring, Seismological data, L'Aquila earthquake, Aftershocks.
}

\section{ABSTRACT}

The aim of this study is the sharing of waveforms recorded by several Istituto Nazionale di Geofisica e Vulcanologia (INGV) temporary stations (managed by the Milan-Pavia section; INGV MI-PV). These stations were installed after the April 6, 2009, Mw 6.3, L'Aquila earthquake (central Italy). The work synthesizes the activities conducted in the field by the INGV MI-PV working group over the three months following the mainshock. The field activities were developed in four different phases that were defined according to their time periods. Starting from April 7, 2009, for the first phase, the temporary stations were installed in correspondence with the more damaged areas. The scope was to record the strongest aftershocks in the days that followed the mainshock. In this phase, the stations were composed of a sixcomponent acquisition system that was coupled with both a weak-motion and a strong-motion sensor. After the first month, the last three phases of installation investigated the seismic responses of sites located in the epicentral area, involving villages within a radius of about $20 \mathrm{~km}$ from the epicenter of the April 6 mainshock. In this way, over four specific time-period phases, the stations were installed in sites with different lithological and geomorphological conditions. The instruments worked from April 7 to July 14, 2009; in this period, 9,155 aftershocks (134,262 accelerometric waveforms and 133,242 velocimetric waveforms), with $M L \leq 5.3$ were recorded. This study describes the dataset of these earthquake waveforms recorded with both velocity and acceleration transducers. Selected waveforms are available through ftp://ftp.mi.ingvit/download/RAIS-TS_rel01/, with their corresponding information concerning instrumental characteristics, installation sites, and earthquakes recorded.

\section{Introduction}

On April 6, 2009, a Mw 6.3 normal faulting event struck close to the city of L'Aquila in the Abruzzo region, central Italy [Ameri et al. 2009, Anzidei et al. 2009, Cirella et al. 2009]. Soon after the mainshock, the first emergency structure of the Centro Nazionale Terremoti (National earthquake centre) of the Istituto Nazionale di Geofisica e Vulcanologia (INGV-CNT; http: / / cnt.rm.ingv.it/) was activated, for the installation of a real-time temporary seismic network in the epicentral area [Chiarabba et al. 2009], with the aim of capturing the migration of the hypocenters of the aftershocks. In the meantime, the INGV Milan-Pavia section (INGV MI-PV) made available the mobile stations of the Rete Accelerometrica in Italia Settentrionale (RAIS; the strong-motion network of northern Italy, http: / / rais.mi.ingv.it) [Augliera et al. 2009], to set up a highdensity temporary network of stations (the RAIS-TS). In this way, INGV MI-PV operated together with the INGV Rome1 section (http://www.roma1.ingv.it/) and the Helmholtz Centre, Potsdam, Germany (http://www.gfzpotsdam.de/portal/gfz/home) in the framework of a coordinated experiment [Cultrera et al. 2009].

A relevant number of stations were installed in the area surrounding the town of L'Aquila (in the upper Aterno valley), near to or inside the most damaged villages [Galli et al. 2009] and where co-seismic surface effects have been observed [Emergeo Working Group 2010].

In the first month after the April 6, 2009, Mw 6.3, L'Aquila mainshock (first phase), the RAIS-TS were mainly installed corresponding to villages that had experienced the greatest damage. In this phase, the RAIS-TS were installed also with the aim of recording the more energetic aftershocks and to evaluate the presence of possibile nonlinear effects; in particular, accelerometric sensors were used to avoid signal saturation.

In the last three phases, the RAIS-TS were moved to several areas up to $20 \mathrm{~km}$ from the town of L'Aquila (see Figure 1), to evaluate the local site responses using ambient noise and/or earthquake recordings. These phases of installation was carried out in agreement with the research groups operating in the area, with the aim of investigating a relevant number of areas, while avoiding superimposition of recording stations.

The present study describes the features of the data collected by RAIS-TS in the epicentral area of the L'Aquila mainshock (Mw 6.3) during these four phases over the three months following the April 6, 2009, mainshock. The RAIS-TS recorded more then 267,000 waveforms that 


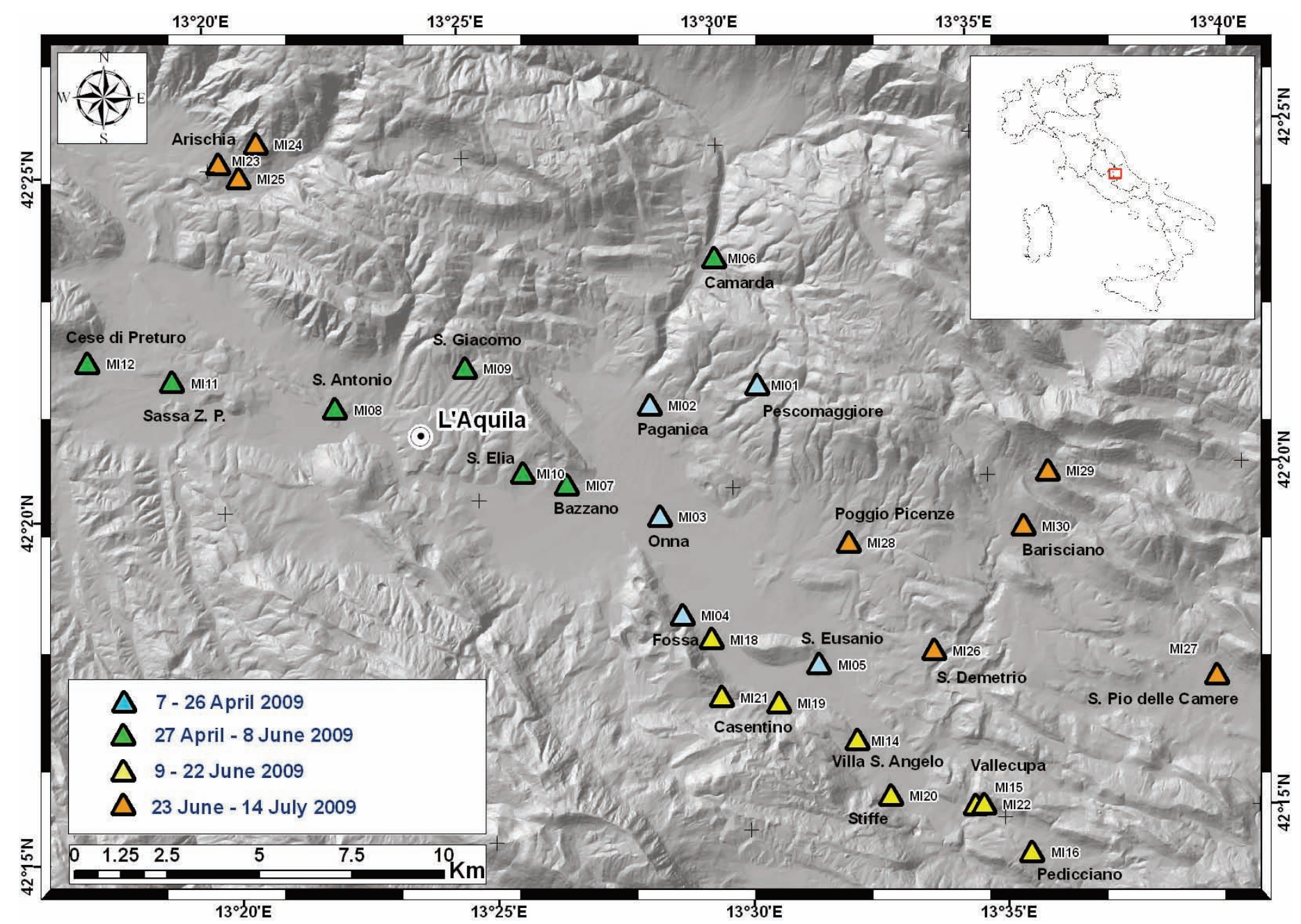

Figure 1. The RAIS-TS stations. The coloured triangles indicate the locations of the temporary stations installed in the different periods (as indicated).

\begin{tabular}{|c|c|c|c|c|c|c|}
\hline Event ID & Data & $\begin{array}{c}\text { Origin } \\
\text { (ime } \\
(\mathbf{G M T})\end{array}$ & $\begin{array}{c}\text { Latitude } \\
(\mathbf{\circ} \mathbf{N})\end{array}$ & $\begin{array}{c}\text { Longitude } \\
(\mathbf{\circ} \mathbf{E})\end{array}$ & $\begin{array}{c}\text { Depth } \\
(\mathbf{K m})\end{array}$ & $\mathbf{M L}$ \\
\hline 20090407092628 & $2009-04-07$ & $09: 26: 28$ & 42.342 & 13.388 & 10.2 & 4.7 \\
\hline 20090407174737 & $2009-04-07$ & $17: 47: 37$ & 42.275 & 13.464 & 15.1 & 5.3 \\
\hline 20090407213429 & $2009-04-07$ & $21: 34: 29$ & 42.380 & 13.376 & 7.4 & 4.2 \\
\hline 20090408225650 & $2009-04-08$ & $22: 56: 50$ & 42.507 & 13.364 & 10.2 & 4.3 \\
\hline 20090409005259 & $2009-04-09$ & $00: 52: 59$ & 42484 & 13.343 & 15.4 & 5.1 \\
\hline 20090409031452 & $2009-04-09$ & $03: 14: 52$ & 42.338 & 13.437 & 18.0 & 4.2 \\
\hline 20090409043244 & $2009-04-09$ & $04: 32: 44$ & 42.445 & 13.420 & 8.1 & 4.0 \\
\hline 20090409193816 & $2009-04-09$ & $19: 38: 16$ & 42.501 & 13.356 & 17.2 & 4.9 \\
\hline 20090413211424 & $2009-04-13$ & $21: 14: 24$ & 42.504 & 13.363 & 7.5 & 4.9 \\
\hline 20090414201727 & $2009-04-14$ & $20: 17: 27$ & 42.530 & 13.288 & 10.4 & 4.1 \\
\hline 20090423151408 & $2009-04-23$ & $15: 14: 08$ & 42.247 & 13.492 & 9.9 & 4.0 \\
\hline 20090423214900 & $2009-04-23$ & $21: 49: 00$ & 42.233 & 13.479 & 9.3 & 4.0 \\
\hline 20090622205840 & $2009-06-22$ & $20: 58: 40$ & 42.446 & 13.356 & 14.2 & 4.5 \\
\hline 20090703110307 & $2009-07-03$ & $11: 03: 07$ & 42.409 & 13.387 & 8.8 & 4.1 \\
\hline 20090712083851 & $2009-07-12$ & $08: 38: 51$ & 42.338 & 13.378 & 10.8 & 4.0 \\
\hline
\end{tabular}

Table 1. Earthquake list for the present study (ML $\geq 4.0$ ). The focal parameters come from the ISIDE bulletin (http://iside.rm.ingv.it/iside/standard/index.jsp; last accessed on December 4, 2009). 


\begin{tabular}{|c|c|c|c|c|c|c|c|c|c|}
\hline Code & Locality & $\begin{array}{l}\text { Lon } \\
\left({ }^{\circ} \mathrm{E}\right)\end{array}$ & $\begin{array}{l}\text { Lat } \\
\left({ }^{\circ} \mathbf{N}\right)\end{array}$ & $\begin{array}{l}\text { EL } \\
(m)\end{array}$ & v. Sens. & A. Sens. & $\begin{array}{l}\text { S. Time } \\
\left(\begin{array}{c}\text { d/m/y } \\
\text { hh:min })\end{array}\right.\end{array}$ & $\begin{array}{l}\text { E. Time } \\
\text { ( d/m/y } \\
\text { hh:min ) }\end{array}$ & $\mathbf{S}$ \\
\hline MI01 & Pescomaggiore & 13.5098 & 42.3580 & 740 & Le3D-Lite & FBA ES-T & $\begin{array}{l}07 / 04 / 09 \\
07: 14\end{array}$ & $\begin{array}{l}27 / 04 / 09 \\
11: 14\end{array}$ & $R$ \\
\hline MI02 & Paganica & 13.4743 & 42.3545 & 648 & Le3D-5s & FBA ES-T & $\begin{array}{l}\text { 07/04/09 } \\
08: 38\end{array}$ & $\begin{array}{l}\text { 29/04/09 } \\
07: 38\end{array}$ & $S$ \\
\hline MI03 & Onna & 13.4757 & 42.3274 & 581 & Le3D-5s & FBA ES-T & $\begin{array}{l}07 / 04 / 09 \\
11: 35\end{array}$ & $\begin{array}{l}\text { 09/06/09 } \\
09: 00\end{array}$ & $S$ \\
\hline MI04 & Fossa & 13.4814 & 42.3031 & 612 & Le3D-Lite & - & $\begin{array}{l}07 / 04 / 09 \\
15: 03\end{array}$ & \begin{tabular}{|l}
$27 / 04 / 09$ \\
$09: 14$
\end{tabular} & $R$ \\
\hline MI05 & $\begin{array}{l}\text { S. Eusanio } \\
\text { Forconese }\end{array}$ & 13.5252 & 42.2895 & 585 & Le3D-5s & FBA ES-T & \begin{tabular}{|l|}
$07 / 04 / 09$ \\
$16: 49$
\end{tabular} & $\begin{array}{l}28 / 04 / 09 \\
08: 05\end{array}$ & $S$ \\
\hline MI06 & Camarda & 13.4979 & 42.3894 & 807 & Le3D-Lite & FBA ES-T & \begin{tabular}{|l|}
$27 / 04 / 09$ \\
$14: 18$
\end{tabular} & $\begin{array}{l}\text { 09/06/09 } \\
08: 48\end{array}$ & $S$ \\
\hline MI07 & Bazzano & 13.4459 & 42.3362 & 662 & Le3D-Lite & FBA ES-T & $\begin{array}{l}27 / 04 / 09 \\
17: 14\end{array}$ & $\begin{array}{l}\text { 09/06/09 } \\
08: 14\end{array}$ & $S$ \\
\hline MI08 & Sant'Antonio & 13.3713 & 42.3574 & 650 & Le3D-Lite & FBA ES-T & $\begin{array}{l}28 / 04 / 09 \\
13.12\end{array}$ & $\begin{array}{l}09 / 06 / 09 \\
10: 12\end{array}$ & $S$ \\
\hline MI09 & San Giacomo & 13.4144 & 42.3658 & 782 & - & FBA ES-T & \begin{tabular}{|l|}
$28 / 04 / 09$ \\
15.20 \\
\end{tabular} & \begin{tabular}{|l|} 
09/06/09 \\
$08: 20$
\end{tabular} & $S$ \\
\hline MI10 & Sant'Elia 1 & 13.4307 & 42.3368 & 607 & Le3D-5s & FBA ES-T & $\begin{array}{l}29 / 04 / 09 \\
11: 32\end{array}$ & $\begin{array}{l}08 / 06 / 09 \\
14: 53\end{array}$ & $S$ \\
\hline MI11 & $\begin{array}{l}\text { Sassa Zona } \\
\text { Polivalente }\end{array}$ & 13.3183 & 42.3659 & 657 & Le3D-5s & - & $\begin{array}{l}29 / 04 / 09 \\
15: 58\end{array}$ & $\begin{array}{l}08 / 05 / 09 \\
11: 00\end{array}$ & $S$ \\
\hline MI12 & Cese di Preturo & 13.2910 & 42.3716 & 672 & - & FBA ES-T & $\begin{array}{l}29 / 04 / 09 \\
17: 00\end{array}$ & $\begin{array}{l}09 / 06 / 09 \\
11: 49\end{array}$ & $S$ \\
\hline MI13 & \begin{tabular}{|l|} 
Sassa Zona \\
Polivalente
\end{tabular} & 13.3183 & 42.3659 & 657 & - & FBA ES-T & $\begin{array}{l}08 / 05 / 09 \\
15: 12\end{array}$ & $\begin{array}{l}08 / 06 / 09 \\
13: 12 \\
\end{array}$ & $S$ \\
\hline MI14 & $\begin{array}{l}\text { Villa } \\
\text { Sant'Angelo }\end{array}$ & 13.5365 & 42.2706 & 587 & Le3D-5s & - & $\begin{array}{l}09 / 06 / 09 \\
15: 15\end{array}$ & $\begin{array}{l}24 / 06 / 09 \\
07: 15\end{array}$ & $S$ \\
\hline MI15 & Vallecupa & 13.5740 & 42.2532 & 680 & Le3D-5s & FBA ES-T & $\begin{array}{l}10 / 06 / 09 \\
15: 46\end{array}$ & $\begin{array}{l}22 / 06 / 09 \\
15: 46\end{array}$ & $S$ \\
\hline MI16 & Pedicciano & 13.5916 & 42.2411 & 749 & Le3D-5s & - & $\begin{array}{l}10 / 06 / 09 \\
17: 52\end{array}$ & $\begin{array}{l}\text { 25/06/09 } \\
09: 08\end{array}$ & $S$ \\
\hline MI18 & Fossa & 13.4904 & 42.2970 & 622 & Le3D-5s & - & $\begin{array}{l}11 / 06 / 09 \\
08: 14\end{array}$ & $\begin{array}{l}22 / 06 / 09 \\
13.14\end{array}$ & $S$ \\
\hline MI19 & Casentino & 13.5114 & 42.2806 & 579 & - & FBA ES-T & $\begin{array}{l}\text { 11/06/09 } \\
09: 56\end{array}$ & $\begin{array}{l}24 / 06 / 09 \\
08: 56\end{array}$ & $S$ \\
\hline MI20 & Stiffe & 13.5464 & 42.2567 & 609 & - & FBA ES-T & $\begin{array}{l}11 / 06 / 09 \\
11: 24\end{array}$ & $\begin{array}{l}24 / 06 / 09 \\
08: 24\end{array}$ & $S$ \\
\hline MI21 & Fossa & 13.4928 & 42.2827 & 741 & Le3D-5s & - & $\begin{array}{l}11 / 06 / 09 \\
15: 54\end{array}$ & $\begin{array}{l}22 / 06 / 09 \\
13: 54\end{array}$ & $R$ \\
\hline MI22 & Vallecupa & 13.5767 & 42.2534 & 692 & Le3D-5s & FBA ES-T & $\begin{array}{l}12 / 06 / 09 \\
17: 20\end{array}$ & $\begin{array}{l}25 / 06 / 09 \\
07: 55\end{array}$ & $R$ \\
\hline MI23 & Arischia & 13.3370 & 42.4185 & 862 & Le3D-5s & FBA ES-T & $\begin{array}{l}23 / 06 / 09 \\
16: 30\end{array}$ & $\begin{array}{l}\text { 14/07/09 } \\
09: 30\end{array}$ & $S$ \\
\hline MI24 & Arischia & 13.3498 & 42.4228 & 1052 & Le3D-5s & - & $\begin{array}{l}23 / 06 / 09 \\
13: 40\end{array}$ & $\begin{array}{l}14 / 07 / 09 \\
08: 30\end{array}$ & $R$ \\
\hline MI25 & Arischia & 13.3437 & 42.4146 & 810 & Le3D-5s & - & $\begin{array}{l}23 / 06 / 09 \\
10: 10\end{array}$ & $\begin{array}{l}14 / 07 / 09 \\
09: 15\end{array}$ & $S$ \\
\hline MI26 & $\begin{array}{l}\text { S. Demetrio } \\
\text { ne' Vestini }\end{array}$ & 13.5630 & 42.2914 & 697 & - & FBA ES-T & $\begin{array}{l}24 / 06 / 09 \\
12: 06\end{array}$ & $\begin{array}{l}14 / 07 / 09 \\
11: 06\end{array}$ & $S$ \\
\hline MI27 & $\begin{array}{l}\text { San Pio delle } \\
\text { Camere }\end{array}$ & 13.6552 & 42.2819 & 807 & - & FBA ES-T & $\begin{array}{l}24 / 06 / 09 \\
14: 29\end{array}$ & $\begin{array}{l}14 / 07 / 09 \\
12: 29\end{array}$ & $S$ \\
\hline MI28 & Poggio Picenze & 13.5370 & 42.3186 & 715 & Le3D-5s & - & $\begin{array}{l}24 / 06 / 09 \\
16: 14\end{array}$ & $\begin{array}{l}\text { 13/07/09 } \\
08: 14\end{array}$ & $S$ \\
\hline MI29 & Barisciano & 13.6035 & 42.3354 & 1191 & Le3D-5s & FBA ES-T & $\begin{array}{l}25 / 06 / 09 \\
12: 50\end{array}$ & $\begin{array}{l}14 / 07 / 09 \\
11: 50 \\
\end{array}$ & $R$ \\
\hline MI30 & Barisciano & 13.5944 & 42.3205 & 899 & Le3D-5s & - & $\begin{array}{l}25 / 06 / 09 \\
14: 50\end{array}$ & $\begin{array}{l}13 / 07 / 09 \\
15: 50\end{array}$ & $S$ \\
\hline
\end{tabular}

Table 2. The RAIS temporary stations. In the last column a preliminary soil $(S)$ classification is reported $(R=\operatorname{rock}$ and $S=\operatorname{soft})$. V. Sens. and A. Sens. indicate velocimetric and accelerometric sensors respectively. S. Time is the starting time, E. Time is the ending time. Lon, Lat and EL indicate Longitude, Latitude and Elevation. 
related to 9,155 aftershocks. In general, the selected waveforms refer to earthquakes with epicentral distances up to $65 \mathrm{~km}, 93 \%$ of which were recorded at distances $<30$ $\mathrm{km}$. In particular, 15 aftershocks with magnitudes $>4.0$ were recorded in the first month, two of which had magnitudes $>5.0$ (Table 1). The aftershocks were recorded by 29 sites, corresponding to 25 localities inside the province of L'Aquila (Table 2). The main scope of the present study is the dissemination of the data for these collected waveforms, to stimulate further research associated with the April 6, 2009, L'Aquila earthquake, and with the sincere belief that it will be useful for both the safety and awareness of the population.

\section{Data acquisition}

Starting from April 7, 2009, several instruments of the RAIS-TS (Figure 1) were installed in the epicentral area of the April 6, 2009, L'Aquila mainshock (Mw 6.3), to achieve the above-mentioned tasks regarding both seismic monitoring and local site-effect investigations. Due to the limited number of instruments available, a particular fourphase installation strategy was adopted to set up different network configurations during the evolution of the sequence. The stations were working globally from April 7 to July 14, 2009, and were installed in sites with different lithological and geomorphological conditions, according to four different phases of network configurations that corresponded to the following time periods:

\section{April 7-26, 2009:}

in this first phase, five RAIS-TS stations were installed corresponding to the more damaged villages [Galli et al. 2009]. Four six-component stations (with three-component velocimetric and three-component accelerometric transducers) and one three-component station (with a threecomponent velocimetric sensor) were installed near the municipalities of Pescomaggiore, Paganica, Onna, Fossa, Sant'Eusanio Forconese (Figure 1).

\section{April 27 - June 8, 2009:}

during this second phase, the RAIS-TS were increased to seven stations (four with six-component and three with three-component instruments), which were installed in selected areas located in the municipality of L'Aquila (near to the source): Camarda, Bazzano, Sant'Antonio, San Giacomo, Sant'Elia, Sassa Zona Polivalente, and Cese di Preturo (Figure 1). The new configuration of the network was set up to investigate the seismic responses of these areas, assessing the soil resonance frequencies through empirical analysis of the events recorded: the horizontal to vertical spectral ratios $(\mathrm{H} / \mathrm{V})$ of earthquakes [Lermo and Chavez-Garcia 1993] and receiver functions [Borcherdt 1970].

\section{June 9-22, 2009:}

in this third phase, the network was composed of eight stations (two with six-component and six with threecomponent instruments) that were installed in areas of the Aterno valley, between $10 \mathrm{~km}$ and $20 \mathrm{~km} \mathrm{SE}$ of the town of L'Aquila, between the municipalities of Fossa and Pedicciano (Figure 1). The instrumentation was installed inside the municipalities of Fossa (two stations), Fagnano, Casentino, Villa S. Angelo, Stiffe, Vallecupa, and Pedicciano.

June 23 - July 14, 2009:

in this last period, the RAIS-TS were moved in both NW and SE directions, to complete the geophysical characterization of the Aterno valley. This last phase included a total of eight installations, five of which were in the municipalities of Poggio Picenze, San Demetrio ne' Vestini, Barisciano (two stations) and San Pio delle Camere (sites located SE of L'Aquila), and three corresponding to the municipality of Arischia, located about $10 \mathrm{~km} \mathrm{NW}$ of L'Aquila (Figure 1).

In general the seismic stations (see Table 3) were equipped with 5 -s or 1-s Lennartz velocimetric sensors and Kinemetrics Episensors (strong-motion sensors), coupled

\begin{tabular}{|c|c|c|c|c|c|}
\hline \multicolumn{6}{|c|}{ Seismic sensors } \\
\hline type & name & $\begin{array}{c}\text { natural } \\
\text { frequency } \\
(\mathrm{Hz})\end{array}$ & sensitivity & poles & zeros \\
\hline Velocimeter & $\begin{array}{l}\text { Lennartz } \\
\text { LE-3D/5s }\end{array}$ & 0.2 & $400 \mathrm{~V} / \mathrm{m} / \mathrm{s}$ & $\begin{array}{l}-0.888+0.888 j \\
-0.888-0.888 j \\
-0.220+0.000 j\end{array}$ & $\begin{array}{l}\text { Triple zero at } \\
\text { the origin }\end{array}$ \\
\hline Velocimeter & $\begin{array}{l}\text { Lennartz } \\
\text { LE-3Dlite }\end{array}$ & 1.0 & $400 \mathrm{~V} / \mathrm{m} / \mathrm{s}$ & $\begin{array}{l}-4.444+4.444 j \\
-4.444-4.444 j \\
-1.083+0.000 j\end{array}$ & $\begin{array}{c}\text { Triple zero at } \\
\text { the origin }\end{array}$ \\
\hline Accelerometer & $\begin{array}{l}\text { Kinemetrics } \\
\text { Episensor } \\
\text { FBA ES-T }\end{array}$ & 200 & $10 \mathrm{~V} / \mathrm{g}$ & & \\
\hline
\end{tabular}

\begin{tabular}{|l|}
\hline Seismic recorder \\
\hline Reftek $130-01$ \\
\hline 3 or 6 Channel recording \\
\hline Resolution 24 bit \\
\hline Clock: GPS \\
\hline Sampling $100 \mathrm{~Hz}$ \\
\hline
\end{tabular}

Table 3. Instrumentation. 


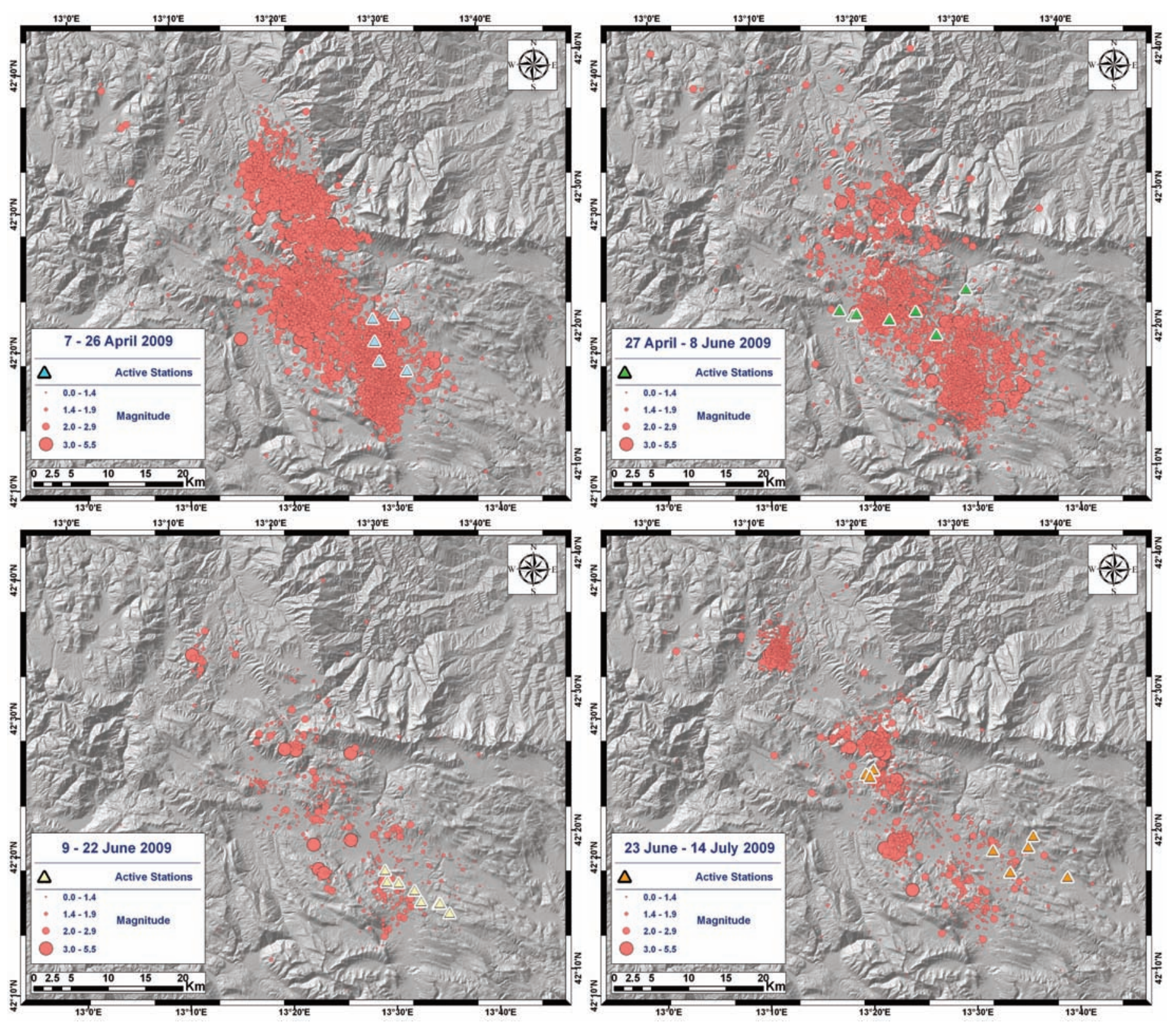

Figure 2. The RAIS-TS recorded events. Each panel shows the seismicity and the station distribution for each period considered (as indicated).

with 24-bit Reftek 130 digital recorders (of both three and six channels). The time code adopted was based on the global positioning system (GPS), and the electricity supplies were assured by solar panels with service batteries. Where possible, the sensors were buried $30 \mathrm{~cm}$ below the soil. The seismic data were recorded on local memory cards and the instruments were sheltered in watertight boxes. Figure 2 shows the seismicity recorded by the RAIS-TS over the whole of the above-mentioned periods.

\section{Data selection}

All of the stations recorded in continuous mode (the data were stored in 1-hour-long data files), so it was possible to recover the time series related to each event from continuous signals. To extract the waveforms recorded from the RAIS-TS over the whole period considered, we refer to the hypocenters reported in the INGV official seismic bulletin
(Italian Seismological Instrumental and Parametric Database; ISIDE; http:/ / iside.rm.ingv.it/iside/standard/index.jsp; last accessed, December 4, 2009).

The ISIDE reference location file is composed of quasireal-time precise locations, data that came from the Italian National Seismic Surveillance, an advanced real-time system for seismic data analysis operated by the INGV-CNT in Rome, Italy. This provides the first location estimate of any Italian earthquake within $40 \mathrm{~s}$ of its origin time, starting from a minimum ML of 1.8 , along with a definitive location within $5 \mathrm{~min}$. Although all of the events detected by the Italian National Seismic Network are located automatically, the ISIDE only reports the list of locations as revised by the seismologist who is in charge of the seismic surveillance activity when the earthquake occurs. This localization is the best evaluation of the hypocenter parameters during the evolution of a seismic sequence. 


\begin{tabular}{|l|l|l|l|}
\hline Magnitude Class & $\begin{array}{l}\text { Pre-event time } \\
(\mathbf{s})\end{array}$ & $\begin{array}{l}\text { Post-event time } \\
\mathbf{( s )}\end{array}$ & $\begin{array}{l}\text { Number of } \\
\text { Events }\end{array}$ \\
\hline$M>=4.0$ & 30 & 240 & 15 \\
\hline $3.0<=M<4.0$ & 30 & 150 & 131 \\
\hline $2.0<=M<3.0$ & 30 & 90 & 1505 \\
\hline $1.0<=M<2.0$ & 30 & 60 & 6984 \\
\hline$M<1.0$ & 30 & 30 & 520 \\
\hline
\end{tabular}

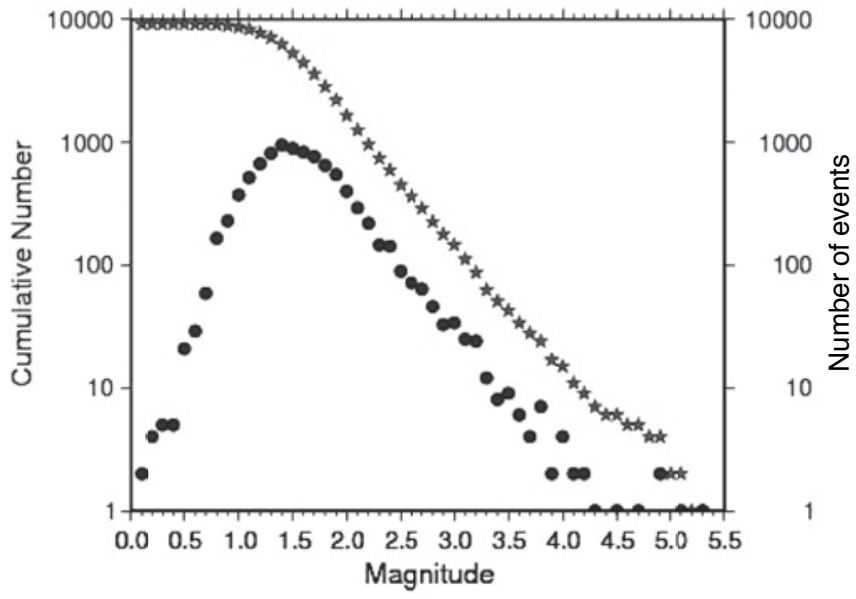

Table 4 (left). Selection criteria for waveform extraction. The increasing post-event times are related to the increasing ML. Figure 3 (right). All the selected earthquakes. The magnitude distribution (circles) and cumulative number of events according to magnitude (stars).

To make the recorded waveforms of the L'Aquila sequence available in a short period, we extracted the data from April 7, 2009 at 07:10 (GMT) to July 14, 2009 at 15:50 using the ISIDE. We considered all of the events, without any magnitude selection, that occurred within a rectangular area limited between $42.15^{\circ}$ and $42.70^{\circ}$ North in latitude and between $13.00^{\circ}$ and $13.80^{\circ}$ East in longitude. For all of the events, the reference time was set to the origin time of the earthquake. We considered a pre-event window for data extraction of $30 \mathrm{~s}$, and a post-event window with a duration that depended on the magnitude of the event (see Table 4). The final events listed include a total of 9,155 earthquakes with ML $\leq 5.3$ (Figure 3). Table 1 reports an example of the event list for the earthquakes with magnitude $>4.0$. The complete list of the extracted dataset is available on the ftp site.

The dataset is composed of a total of 267,504 waveforms, 134,262 of which are strong-motion waveforms, and 133,242 of which are velocimetric data. Figure 4 shows the magnitude versus epicentral distance distribution of the whole dataset. The selected earthquakes were recorded by a variable number of stations, depending on the network configuration at the time. The coincidence list in Table 5 shows an example for the events with magnitudes $>4.0$. Even if in the present study we operated a selection based on ISIDE, since the waveforms were recorded in continuous mode, further time series can, however, be recovered on demand from continuous recordings.

\section{Dataset structure and data format}

The earthquake waveforms were at first extracted from continuous signals, and then converted into Little-endian SAC binary files (http: / / www.iris.washington.edu/ software/sac/) [Tapley and Tull 1992]. Each time series was individually written into the SAC file data section as an evenly sampled data sequence. Consequently, the SAC header variables LEVEN and IFTYPE were set to TRUE and ITIME, respectively. All of the data were sampled at 100 sps and the data values are expressed in counts. Ground motion units can be obtained through the SAC header variables USER0 and USER1, respectively set as sensitivity $(\mathrm{V} / \mathrm{m} / \mathrm{s}$ and $\mathrm{V} / \mathrm{g}$ for velocimetric and accelerometric sensors, respectively), and digitization constant (V/count) and KUSER0 (gain). The extracted waveforms were baseline corrected using the SAC command RTREND, which removes any linear trend from

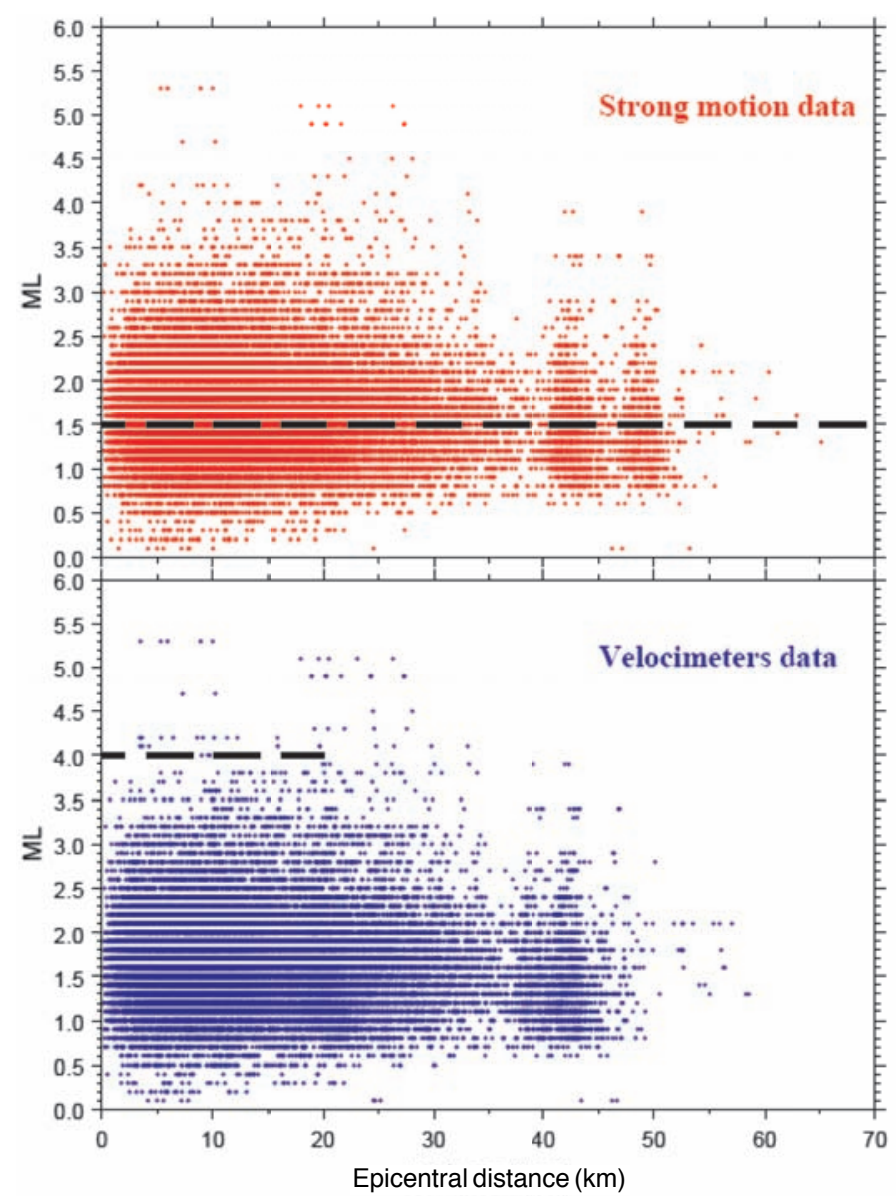

Figure 4. Magnitude versus epicentral distance distribution of the events recorded. Top panel: records from the strong-motion sensors. Bottom panel: records from the weak-motion sensors. In both panels, the data located above and below the dashed lines indicate records with low signalto-noise ratio (top panel, for the accelerometers) and possible signal saturation (bottom panel, for velocimeters). 

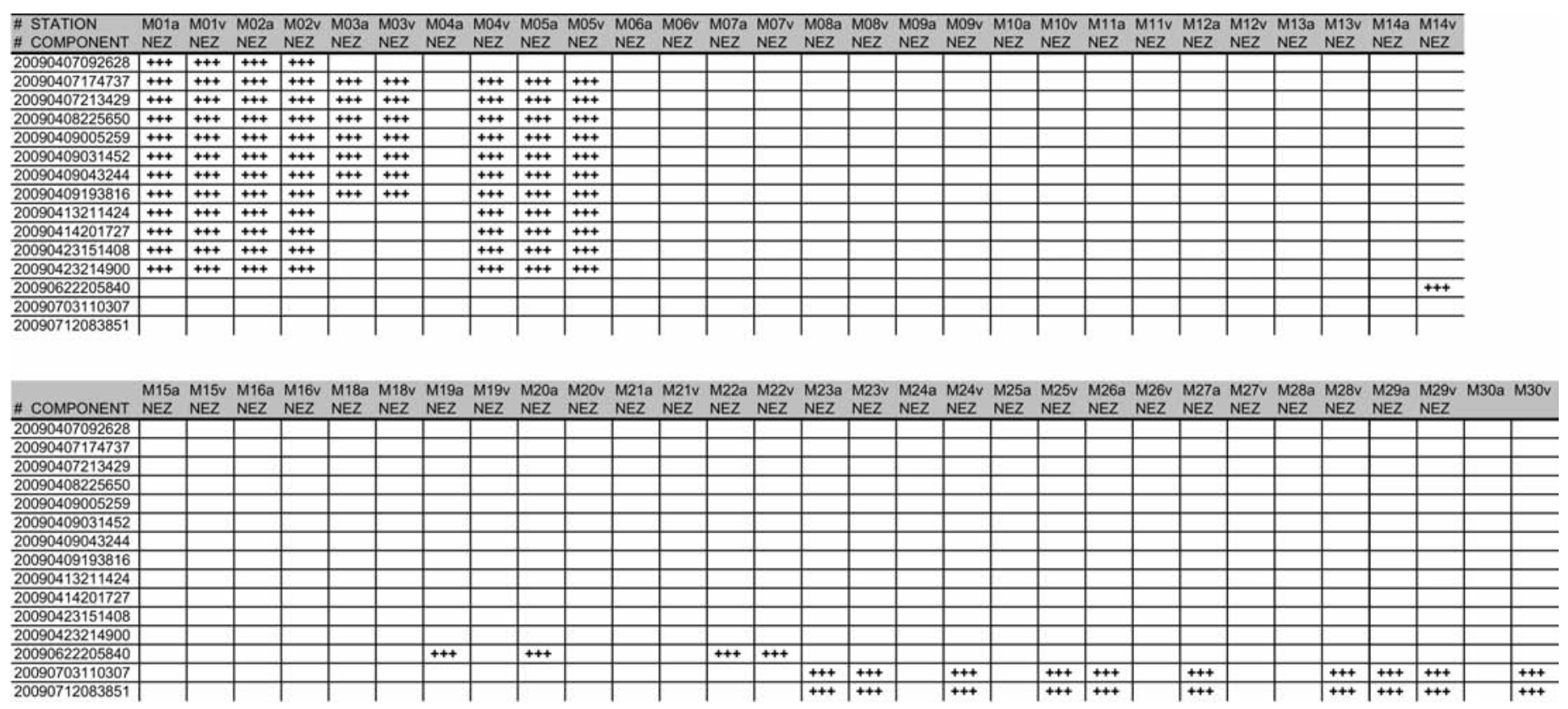

Table 5. Coincidence list of the dataset events for $M \geq 4.0$. STATION: a = accelometer; $\mathrm{v}=$ velocimeter. COMPONENT: $\mathrm{N}=\mathrm{North}-\mathrm{South}$; $=$ East-West; $Z=$ Up-Down. For each event and for each station the existing components are marked as «+».

the data and media removed using the SAC command RMEAN. The waveforms were not corrected for the instrument response and were not filtered. The SAC header parameters were generally set according to the conventions adopted by the SAC Users Manual (http://www.iris.edu/manuals/sac/manual.html), with a certain number of variables customized for the present dataset. The complete description of the SAC header variables is reported in the Appendix.

The waveforms datasets were organised following an event code, which was defined by the origin time of the earthquake (expressed as year, month, day, hour, minute and second), as reported in ISIDE. The dataset was structured into directories with names that correspond to the event codes. Each directory contains SAC files with the waveforms related to the stations that recorded the corresponding earthquake. The file names are composed of four different sections: extraction time (year, month, day, hour, minute and second, defined according to the above-mentioned pre-event time, which was selected to be $30 \mathrm{~s}$ before the origin time of the earthquake); station code (four characters); channel (according to the SEED-format conventions; see below); and file type (e.g. .sac).

The SEED-format convention for the channel naming adopts three characters, each of which describes a single aspect of the data. The first character specifies the general sampling rate and the response frequency band of the instrument: for example $E$ stands for «extremely short period instrument with a sample rate in the range of 80-250 $\mathrm{Hz}$ and a corner period $<10 \mathrm{~s}$. The second character specifies the sensor family: $H$ stands for "high-gain seismometer» and $N$ for accelerometer data. The third character specifies the orientation code ( $\mathrm{Z}, \mathrm{N}, \mathrm{E}$ for traditional vertical, North-South, East-West). For more information, please refer to Appendix A of the SEED reference manual (Incorporated Research Institute for Seismology; IRIS, 2009; http://www.iris.washington.edu/manuals/SEED_appA.htm). For example, following the ISIDE origin time, an event that occurred on April 9, 2009 (at 19:38:16) and recorded by station MI01 (equipped with a Lennartz Le3D-Lite velocimetric sensor, corner period $1 \mathrm{~s}$ and sampling $100 \mathrm{sps}$ ) was extracted at 19:37:46: in this case the name of the related file (included in the folder /20090409193816/) will be 20090409193746_MI01.EHZ.sac.

All of the extracted SAC waveforms are included in the section /waveforms/ of the dataset in which the directories are grouped according to four magnitude classes that correspond to the different earthquakes: $3.0 \leq \mathrm{ML}<5.5$ (146 events); $2.0 \leq \mathrm{ML}<3.0$ (1,505 events); $1.5 \leq \mathrm{ML}<2.0$ (3,673 events); $0.0 \leq \mathrm{ML}<1.5$ (3,831 events). Each class corresponds to a uncompressed tar archive file, which also includes the information files of the whole dataset. The information files are subdivided into sections /maps/ and into /files/, the former of which includes KML files to display the stations and epicentres in an Earth browser such as Google Earth (http://earth.google.com). The section /files/ includes bulletin files, coincidence files, station books, and instrument information. The complete structure of the datasets is summarized in Figure 5.

\section{Conclusions}

The dataset presented in the present study consists of more than 267,000 waveforms related to 9,155 aftershocks that occurred after the April 6, 2009, Mw 6.3, L'Aquila earthquake, and were recorded by the RAIS-TS over the period of April, 7 - July 14, 2009. The selected waveforms are 
/ DATA_SET_M_0.0-1.4 / files / bulletin_files/D bull_ISIDE_ALL

10 bull_ISIDE_M_0.0_1.4

/ 1 bull_ISIDE_M_1.5_1.9

17 bull_ISIDE_M_2.0 2.9

/ 0 bull_ISIDE_M_3.0_5.5

10 bull_ISIDE_N

/ coincidence_files/ [coinc-tab.MO0-14

/ O coinc-tab.M15-19

/ 0 coinc-tab.M20-29

/ 0 coinc-tab.M30-55

图 coinc-tab-MO0-14

圂 coinc-tab-M15-19

/ 질 coinc-tab-M20-29

1 질 coinc-tab-M30-55

/ stations_book/ ₹ M101 .... ₹

/ poles_and_zeros/ $\square$ Lennartz_LE3D5s.gse

1 a abruzzo_stations_file

[. Lennart__LE3Dlite.gse

/ \# sac_header_variables

/maps / INGV_RAIS_Events

1 RAIS_temporary_stations

/WaveformS/ 20090407080052 / 20090407080022 _MI01.EHE.sac /20090407080022_MI01.EHN.sac \begin{tabular}{ll}
\multicolumn{1}{c}{$/ 2009040$} \\
$/ 20090407092628 / \ldots$ \\
$/ \ldots$
\end{tabular}

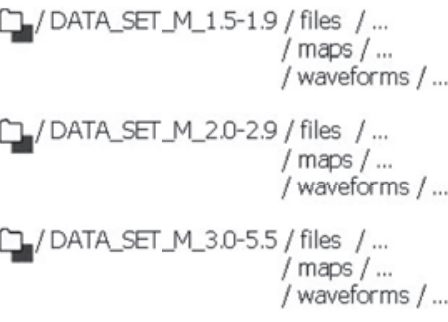

\section{/ README}

Figure 5. Dataset structure (see text for explanation).

all available in SAC format, and they correspond to events with a maximum epicentral distance of $65 \mathrm{~km}$. In particular, the dataset includes 15 events with ML $>4$, two of which have an $\mathrm{ML}>5$, which were recorded at epicentral distances of $<30 \mathrm{~km}$ (Table 1 ).

The waveforms have been extracted from signals recorded in continuous mode after selection of the corresponding time windows, based on the origin times reported in the ISIDE bulletin. The localizations used for this dataset corresponded to the best evaluations of hypocenter parameters available in December, 2009. Minimal pre-processing was applied to all of the records, which basically consisted of linear-trend removing. The location parameters and other information about the recorded events, station characteristics and instrumental settings are included in the SAC file headers. It is worth noting that in the case of energetic events recorded by stations close to the epicenter, the weak-motion channels (velocimetric sensor) show saturated waveforms (see Figures 4 and 6, dashed lines in the bottom panels). In contrast, the strong-motion stations that recorded all of the strongest aftershocks can show low-quality data (in terms of signal-to-noise ratios) related to weak motions ( $M L \leq 1.5)$, especially if they were recorded at distances greater than about $20 \mathrm{~km}$. In any case, the database described in the present study includes all of the records. It will be the responsability of the final users to focus their attention on these considerations.

The maximum recorded peak ground acceleration was $0.69 \mathrm{~g}$ at $5.4 \mathrm{~km}$ of epicentral distance (station MI05) during the April 7, 2009, ML 5.3, earthquake (Figure 7).

As is usual in seismic sequences, the first period of activity was characterized by a high seismic rate, with a large number of events over short time periods. The waveforms belonging to the different earthquakes often overlapped within the same time windows (Figure 8).

The 267,504 selected waveforms and the corresponding information relating to the instruments, installation sites and recorded earthquakes are all downloadable from ftp: / / ftp.mi.ingv.it/download/RAIS-TS_rel01/

Acknowledgements. The authors would like to thank all of the people that helped in the fieldwork and analysed the waveforms. There were a lot of people involved, and they should all be noted. Particular thanks go to our colleagues of INGV MI-PV: Gabriele Ameri, Chiara Ladina, Sara Lovati, Lucia Luzi, Mariano Maistrello, Francesca Pacor, Carlo Piccarreda, Davide Piccarreda, Rodolfo Puglia and Fabrizio Galadini. Thanks are also due to our colleagues of GFZ and INGV-Rome1 for their collaboration during the fieldwork.
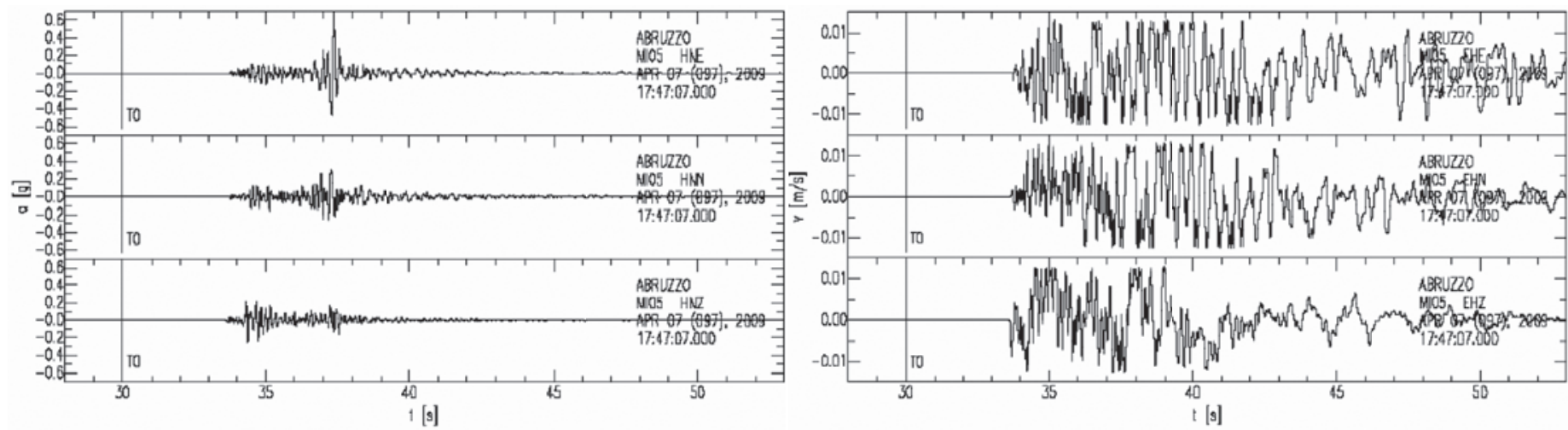

Figure 6. April 7, 2009, ML = 5.3, aftershock recorded at station MI05 by a six-component acquisition system equipped with both strong-motion (left panel; HNE, HNN and HNZ for East-West, North-South and vertical components) and weak-motion (right panel; EHE, EHN and EHZ for East-West, NorthSouth and vertical components) sensors. It is worth noting that the strong-motion sensor (time sequences on the left) recorded the event without saturation. 


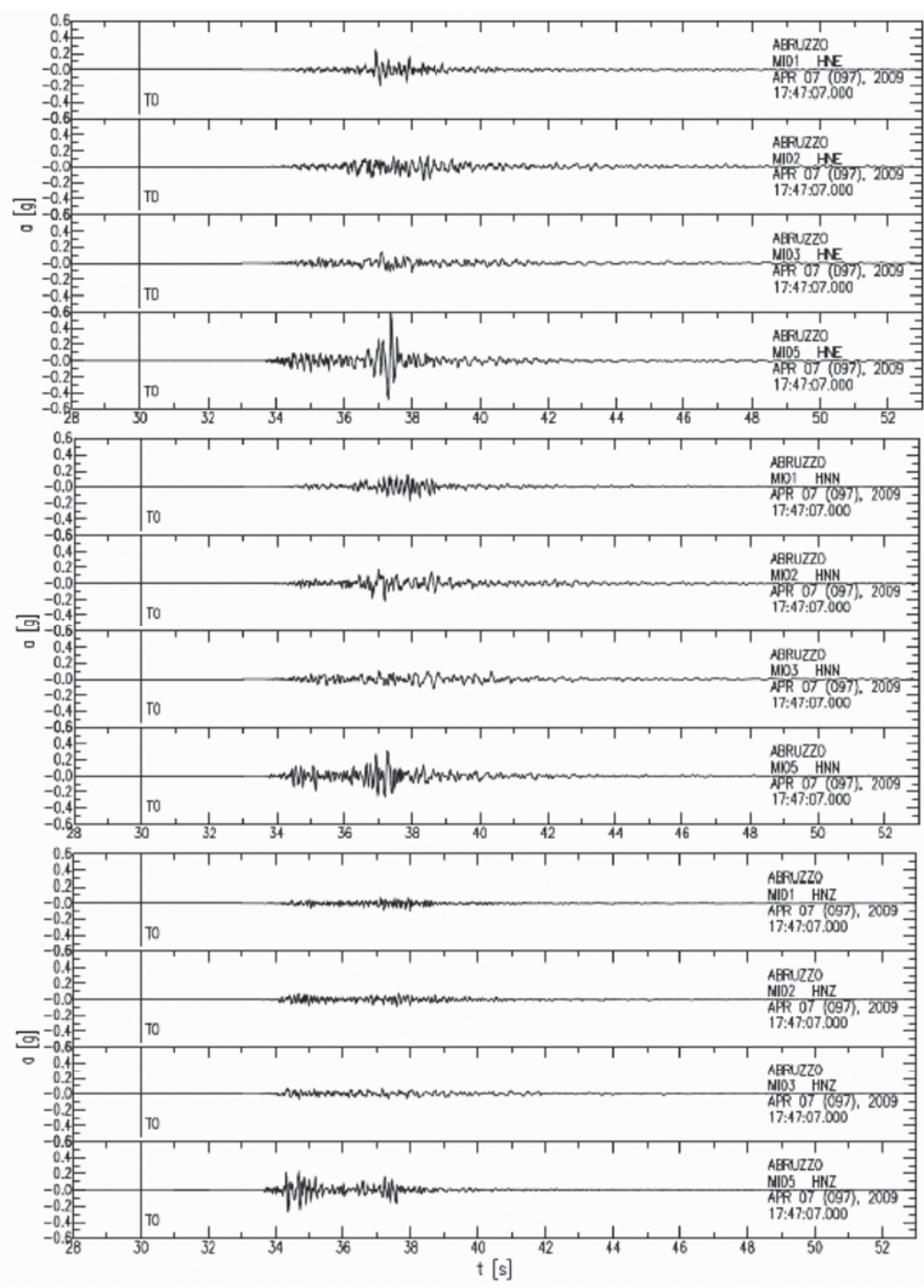

Figure 7. April 7, 2009, ML = 5.3, aftershock recorded at strong-motion stations MI01, MI02, MI03 and MI05 (top panel, East-West; middle panel, NorthSouth; and bottom panel, vertical components) in the near source (epicentral distances $<10 \mathrm{~km}$ ).
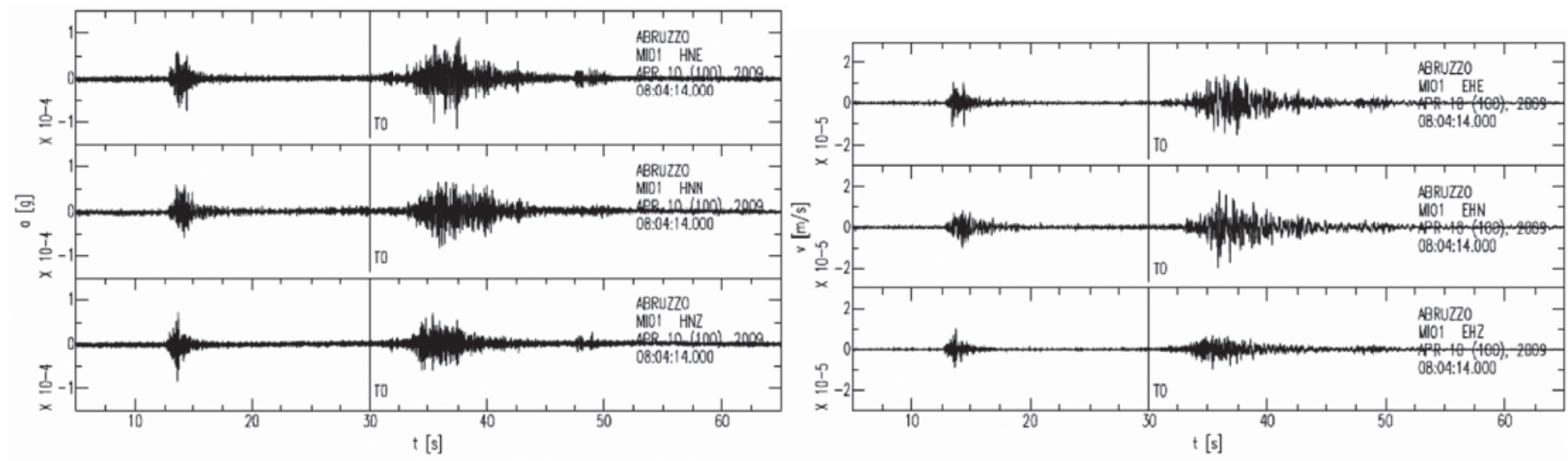

Figure 8. Waveforms of a ML $=1.5$ earthquake recorded at station MI01 by a six-component acquisition system equipped with both strong-motion (left panel) and weak-motion (right panel) sensors. At least two of these events overlap between $30 \mathrm{~s}$ and $40 \mathrm{~s}$, and a small event occurred before the selected earthquake was detected (between $10 \mathrm{~s}$ and $20 \mathrm{~s}$ ). 


\section{References}

Ameri, G., M. Massa, D. Bindi, E. D'Alema, A. Gorini, L. Luzi, M. Marzorati, F. Pacor, R. Paolucci, R. Puglia and C. Smerzini (2009). The 6 April 2009, Mw 6.3, L'Aquila (central Italy) earthquake: strong-motion observations, Seism. Res. Lett., 80., 951-966.

Anzidei, M., E. Boschi, V. Cannelli, R. Devoti, A. Esposito, A. Galvani, D. Melini, G. Pietrantonio, F. Riguzzi, V. Sepe and E. Serpelloni (2009). Coseismic deformation of the destructive April 6, 2009 L'Aquila earthquake (central Italy) from GPS data, Geophys. Res. Lett., 36, L17307.

Augliera, P., E. D'Alema, S. Marzorati and M. Massa (2009). A strong-motion network in northern Italy: detection capabilities and first analyses, Bull. Earthquake Eng., doi: 10.1007/ s10518-009-9165-y.

Borcherdt, R.D. (1970). Effects of local geology on ground motion near San Francisco Bay, Bull. Seism. Soc. Am., 60, 29-61.

Chiarabba, C., A. Amato, M. Anselmi, P. Baccheschi, I. Bianchi, M. Cattaneo, G. Cecere, L. Chiaraluce, M.G. Ciaccio, P. De Gori, G. De Luca, M. Di Bona, R. Di Stefano, L. Faenza, A. Govoni, L. Improta, F.P. Lucente, A. Marchetti, L. Margheriti, F. Mele, A. Michelini, G. Monachesi, M. Moretti, M. Pastori, N. Piana Agostinetti, D. Piccinini, P. Roselli, D. Seccia and L. Valoroso (2009). The 2009 L'Aquila (central Italy) Mw 6.3 earthquake: Main shock and aftershocks, Geophys. Res. Lett., 36, L18308.

Cirella, A., A. Piatanesi, M. Cocco, E. Tinti, L. Scognamiglio, A. Michelini, A. Lomax and E. Boschi (2009). Rupture history of the 2009 L'Aquila (Italy) earthquake from nonlinear joint inversion of strong motion and GPS data, Geophys. Res. Lett., 36, L19304.

Cultrera, G. and L. Luzi with G. Ameri, P. Augliera, R.M. Azzara, F. Bergamaschi, E. Bertrand, P. Bordoni, F. Cara, R. Cogliano, E. D'Alema, D. Di Giacomo, G. Di Giulio, A.M. Duval, A. Fodarella, G. Franceschina, M.R. Gallipoli, P. Harabaglia, C. Ladina, S. Lovati, S. Marzorati, M. Massa, G. Milana, M. Mucciarelli, F. Pacor, S. Parolai, M. Picozzi, M. Pilz, R. Puglia, S. Pucillo, J. Régnier, G. Riccio, J. Salichon and M. Sobiesiak (2009). Valutazione della risposta sismica locale di alcuni siti dell'alta e media valle dell'Aterno, Progettazione Sismica, 3, 69-73.

EMERGEO Working Group (2010). Evidence for surface rupture associated with the Mw 6.3 L'Aquila earthquake sequence of April 2009 (central Italy), Terra Nova, 22, 43-51.

Galli, P., R. Camassi, R. Azzaro, F. Bernardini, S. Castenetto, D. Molin, E. Peronace, A. Rossi, M. Vecchi and A. Tertulliani (2009). Terremoto de L'Aquila del 6 aprile 2009: distribuzione delle intensità macrosismiche ed implicazioni sismotettoniche, Il Quaternario, 22, 235-246.

Lermo, J. and F.J. Chavez-Garcia (1993). Site effect evaluation using spectral ratio with only one station, Bull. Seism. Soc. Am., 83, 1574-1594.
Tapley, W.C. and J.E. Tull (1992). SAC - Seismic Analysis Code, USERS MANUAL, Rev.4., University of California (USA).

Corresponding author: Dr. Paolo Augliera, Istituto Nazionale di Geofisica e Vulcanologia, sezione di Milano-Pavia, Milano, Italy; e-mail: paolo.augliera@mi.ingv.it

(C) 2010 by the Istituto Nazionale di Geofisica e Vulcanologia. All rights reserved. 
Appendix

\section{SAC HEADER}

EXAMPLE FILE: 20090408175805_MI02.HNZ.sac

\begin{tabular}{|c|c|c|c|c|}
\hline Variable & Description & Possible Values & $\begin{array}{l}\text { RAIS-TS } \\
\text { field }(*)\end{array}$ & Typical value \\
\hline NPTS & $\begin{array}{l}\text { Number of points per } \\
\text { data component. }\end{array}$ & & & 18000 \\
\hline B & $\begin{array}{l}\text { Beginning value of the } \\
\text { independent variable }\end{array}$ & & & $0.000000 e+00$ \\
\hline$A$ & $\begin{array}{l}\text { Ending value of the } \\
\text { independent variable }\end{array}$ & & & $1.800000 \mathrm{e}+02$ \\
\hline IFTYPE & Type of file & $\begin{array}{l}=\text { ITIME }\{\text { Time series file }\} \\
=\text { IRLIM }\{\text { Spectral file---real } \\
\text { and imaginary\} } \\
=\text { IAMPH }\{\text { Spectral file--- } \\
\text { amplitude and phase } \\
=\text { IXY }\{\text { General } x \text { versus y } \\
\text { data }\} \\
=\text { IXYZ }\{\text { General XYZ (3-D) } \\
\text { file }\}\end{array}$ & & TIME SERIES FILE \\
\hline LEVEN & $\begin{array}{l}\text { TRUE if data is evenly } \\
\text { spaced }\end{array}$ & & & TRUE \\
\hline DELTA & $\begin{array}{l}\text { Increment between } \\
\text { evenly spaced samples }\end{array}$ & & & $1.000000 \mathrm{e}-02$ \\
\hline DEPMIN & $\begin{array}{l}\text { Minimum value of } \\
\text { dependent variable }\end{array}$ & & & $-6.655318 e+04$ \\
\hline DEPMAX & $\begin{array}{l}\text { Maximum value of } \\
\text { dependent variable }\end{array}$ & & & $4.807683 e+04$ \\
\hline DEPMEN & $\begin{array}{l}\text { Mean value of dependent } \\
\text { variable }\end{array}$ & & & $2.723649 \mathrm{e}-06$ \\
\hline $\mathrm{O}$ & $\begin{array}{l}\text { Event origin time } \\
\text { (seconds relative to } \\
\text { reference time.) }\end{array}$ & & & 30 \\
\hline $\mathrm{KO}$ & $\begin{array}{l}\text { Event origin time } \\
\text { identification. }\end{array}$ & & & (T0) \\
\hline KZDATE & $\begin{array}{l}\text { Alphanumeric form of } \\
\text { GMT reference date }\end{array}$ & & & $\begin{array}{lll}\text { APR } & 08 & (098), \\
2009 & & \end{array}$ \\
\hline KZTIME & $\begin{array}{l}\text { Alphanumeric form of } \\
\text { GMT reference time }\end{array}$ & & & 17:58:05.000 \\
\hline IZTYPE & $\begin{array}{l}\text { Reference time } \\
\text { equivalence }\end{array}$ & $\begin{array}{l}=\text { IUNKN (Unknown) } \\
=\text { IB (Begin time) } \\
=\text { IDAY (Midnight of reference } \\
\text { GMT day) } \\
=\text { IO (Event origin time) } \\
=\text { IA (First arrival time) } \\
=\text { ITn (User defined time pick } \\
n, n=0,9)\end{array}$ & & BEGIN TIME \\
\hline KINST & $\begin{array}{l}\text { Generic name of } \\
\text { recording instrument. }\end{array}$ & & $\mathbf{x}$ & RTF130 \\
\hline KSTNM & Station name & & $\mathbf{x}$ & MIO2 \\
\hline CMPAZ & $\begin{array}{l}\text { Component azimuth } \\
\text { (degrees clockwise from } \\
\text { north) }\end{array}$ & & $\mathbf{x}$ & $0.000000 e+00$ \\
\hline CMPINC & $\begin{array}{l}\text { Component incident } \\
\text { angle (degrees from } \\
\text { vertical). }\end{array}$ & & $\mathbf{x}$ & $0.000000 e+00$ \\
\hline STLA & $\begin{array}{l}\text { Station latitude (degrees, } \\
\text { north positive) }\end{array}$ & & $\mathbf{x}$ & $4.235449 e+01$ \\
\hline STLO & $\begin{array}{l}\text { Station longitude } \\
\text { (degrees, east positive). }\end{array}$ & & $\mathbf{x}$ & $1.347428 \mathrm{e}+01$ \\
\hline STEL & $\begin{array}{l}\text { Station elevation } \\
\text { (meters). }\end{array}$ & & $\mathbf{x}$ & $6.480000 e+02$ \\
\hline KEVNM & Event name & & $\mathbf{x}$ & ABRUZZO \\
\hline
\end{tabular}




\begin{tabular}{|c|c|c|c|c|}
\hline Variable & Description & Possible Values & $\begin{array}{l}\text { RAIS-TS } \\
\text { field }(*)\end{array}$ & Typical value \\
\hline EVLA & $\begin{array}{l}\text { Event latitude (degrees, } \\
\text { north positive) }\end{array}$ & & $\mathbf{x}$ & $4.236400 e+01$ \\
\hline EVLO & $\begin{array}{l}\text { Event longitude (degrees, } \\
\text { east positive). }\end{array}$ & & $\mathbf{x}$ & $1.339600 \mathrm{e}+01$ \\
\hline EVDP & Event elevation (meters) & & $\mathbf{x}$ & $8.800000 e+00$ \\
\hline DIST & $\begin{array}{l}\text { Station to event distance } \\
(\mathrm{km}) \text {. }\end{array}$ & & & $6.535192 \mathrm{e}+00$ \\
\hline$A Z$ & $\begin{array}{l}\text { Event to station azimuth } \\
\text { (degrees). }\end{array}$ & & & $9.927607 e+01$ \\
\hline BAZ & $\begin{array}{l}\text { Station to event azimuth } \\
\text { (degrees). }\end{array}$ & & & $2.793286 e+02$ \\
\hline GCARC & $\begin{array}{l}\text { Station to event great } \\
\text { circle arc length } \\
\text { (degrees). }\end{array}$ & & & $5.879549 e-02$ \\
\hline LOVROK & $\begin{array}{l}\text { TRUE if it is okay to } \\
\text { overwrite this file on disk. }\end{array}$ & & & TRUE \\
\hline USERO & Sensitivity & $\begin{array}{l}\text { Velocimetric Lennartz } \\
\text { sensor }=400 ; \\
\text { Accelerometer Kinemetrics } \\
\text { sensor }=10\end{array}$ & $\mathbf{x}$ & $1.000000 \mathrm{e}+01$ \\
\hline USER1 & $\begin{array}{l}\text { Digitalization constant } \\
\text { V/C }\end{array}$ & $1.58997 e-06$ & $\mathbf{x}$ & $1.589970 \mathrm{e}-06$ \\
\hline USER2 & Trend removal & ( $1=$ rtrend on; $0=$ rtrend off $)$ & $\mathbf{x}$ & $1.000000 \mathrm{e}+00$ \\
\hline USER3 & Tapering & On $=1 ;$ Off $=0$ & $\mathbf{x}$ & $0.000000 e+00$ \\
\hline USER4 & Mean removal & ( $1=$ rmean on; $0=$ rmean off $)$ & $\mathbf{x}$ & $1.000000 \mathrm{e}+00$ \\
\hline USER5 & filtering procedure & $\begin{array}{l}\text { (1=Butterworth filter on; } 0= \\
\text { Butterworth filter off) }\end{array}$ & $\mathbf{x}$ & $0.000000 e+00$ \\
\hline KUSERO & Sensitivity unit \# gain & $\begin{array}{l}\text { Velocimeter sensor }=\mathrm{V} / \mathrm{m} / \mathrm{s} \\
\text { Accelerometric sensor }=\mathrm{V} / \mathrm{g} \\
\text { Gain }=1 \text { or } 32\end{array}$ & $\mathbf{x}$ & $\mathrm{V} / \mathrm{g} \# 1$ \\
\hline KUSER1 & Trace unit & Count & $\mathbf{x}$ & Count \\
\hline KUSER2 & Sensor model & $\begin{array}{l}\text { Episens=Kinemetric } \\
\text { Episensor; LE3D-1s=Lennartz } \\
\text { Lite } 1 \text { second; LE3D- } \\
5 s=\text { Lennartz } 5 \text { seconds }\end{array}$ & $\mathbf{x}$ & Episens \\
\hline NVHDR & $\begin{array}{l}\text { Header version number. } \\
\text { Current value is the } \\
\text { integer } 6 \text {. Older version } \\
\text { data (NVHDR }<6 \text { ) are } \\
\text { automatically updated } \\
\text { when read into sac }\end{array}$ & & & 6 \\
\hline NORID & Origin ID & & & 0 \\
\hline NEVID & Event ID & & & 0 \\
\hline LPSPOL & $\begin{array}{l}\text { TRUE if station } \\
\text { components have a } \\
\text { positive polarity (left- } \\
\text { hand rule). }\end{array}$ & & & FALSE \\
\hline LCALDA & $\begin{array}{l}\text { TRUE if DIST, AZ, BAZ, } \\
\text { and GCARC are to be } \\
\text { calculated from station } \\
\text { and event coordinates. }\end{array}$ & & & TRUE \\
\hline KCMPNM & Component name & $\begin{array}{l}\text { HNZ= Accelerometric vertical } \\
\text { component (Up-Down) } \\
\text { HNN= Accelerometris } \\
\text { orizzontal component (North- } \\
\text { South) } \\
\text { HNE= Accelerometris } \\
\text { orizzontal component (East- } \\
\text { West) } \\
\text { EHZ=Velocimetric vertical } \\
\text { component (Up-Down) } \\
\text { EHN= Velocimetric orizzontal } \\
\text { component (North-South) } \\
\text { EHE=Velocimetric orizzontal } \\
\text { component (East-West); } \\
\text { SEED convention }\end{array}$ & $\mathbf{x}$ & HNZ \\
\hline KNETWK & Name of seismic network. & & $\mathbf{x}$ & RAIS \\
\hline
\end{tabular}


L'AQUILA TEMPORARY NETWORK

\begin{tabular}{|l|l|l|c|l|}
\hline Variable & Description & Possible Values & $\begin{array}{l}\text { RAIS-TS } \\
\text { field (*) }\end{array}$ & Typical value \\
\hline MAG & Event magnitude. & & $\mathbf{x}$ & $3.200000 \mathrm{e}+00$ \\
\hline IMAGTYP & Magnitude type & $\begin{array}{l}\text { = IMB (Bodywave Magnitude) } \\
\text { = IMS (Surfacewave } \\
\text { Magnitude) } \\
\text { = IML (Local Magnitude) } \\
\text { = IMW (Moment Magnitude) } \\
\text { = IMD (Duration Magnitude) } \\
\text { = IMX (User Defined } \\
\text { Magnitude) }\end{array}$ & Local Magnitude \\
\hline
\end{tabular}

$\left.{ }^{*}\right)$ The user defined parameters of the RAIS-TS network are labeled with " $x$ ". 